Archaeological Journal

\title{
The Carlisle Bushel
}

\section{By R. S. Ferguson}

To cite this article: By R. S. Ferguson (1885) The Carlisle Bushel, Archaeological Journal, 42:1, 303-311, DOI: $10.1080 / 00665983.1885 .10852178$

To link to this article: http://dx.doi.org/10.1080/00665983.1885.10852178

曲 Published online: 15 Jul 2014.

Submit your article to this journal 중

Q View related articles $₫$ 


\section{THE CARLISLE BUSHEL.}

By R. S. FERGUSON, F.S.A.

$A$ bushel is defined as " a measure of capacity for things dry: as grains, pulse, dry fruits, etc., containing four pecks, or eight gallons, or one-eighth of a quarter." A great many places had local bushels of different dimensions in different places.

At Abingdon and Andover a bushel contains nine gallons; at Appleby and Penrith a bushel of pease, rye, and wheat contains 16 gallons; of barley, big malt, mixt malt, and oats, 20 gallons. A bushel contains, at Carlisle, 24 gallons; at Chester, a bushel of wheat, rye, etc., contains 32 gallons, and of oats 40 , etc.. etc. ${ }^{2}$

An interesting note on the Carlisle bushel is furnished by Mr. Ornsby. He says :-

The following particulars are perhaps worth noting. They occur in a paper (Dom. Charles I., ccccx, 165) which is undated, but which appears to have been sent to Sir Jacob Astley, or one of his officers, some time in 1639 or 1640 , in answer to enquiries about the price of provisions for the king's troops. 'A particular note of the prices of corne used in Carlisle, and the measure thereof. Imprimis our bushell is 24 gallons, which gallon is 4 wine quarts and a pint. Bigg is to be bought from $5 \mathrm{~s}$. to $7 \mathrm{~s}$. a bushell. Pease from 2s. 6d. to $4 \mathrm{~s}$. the bushell. Malt 6s. or thereabout the bushell. Wheat at $16 \mathrm{~s}$. the bushell, Malt $6 \mathrm{~s}$. or thereabouts the bushell. Wheat at 16s. the bushell. Rye at 10s. the bushell. This note I had from Mr. Maior of Carlisle. Westmerland. Corne is much at the same rates of Cumberland, but the measure is not so much by 4 gallons in a bushell. ${ }^{3}$

In 1677, Machel sends to the vicar of Melmerly a series of questions, ${ }^{4}$ of which No. 3 is "How much do you reckon to a peck?"

In the terriers ${ }^{5}$ for Hutton and Greystock, delivered to bishop Nicolson at his primary visitation, 1704, we find varying measures. Thus at Hutton three people paid

\footnotetext{
1 Encyclopcedia Britannica, 4th edition, 1810 , sub voce bushel.

2 Ibid.

${ }^{3}$ Lord William Howard's Household Books, Surtees Society, vol. xlviii, p. lxxv.

${ }^{4}$ Machel. MSS. vol. vi., penes the Dean and Chapter of Carlisle.

${ }^{3}$ Miscellany. Accounts of the Diocese of Carlisle. (Thurnam, Carlisle, 1877.)
} 
peck corn to the parson by the Penrith peck, all the others by a peck of their own kept at William Oliphant's. At Greystoke, bushel corn was paid 20 gallons to the bushel, except Thwait Hall, which only paid 16 .

It would be easy to multiply similar instances of deviations from the legal standards : and these deviations it has been found almost impossible to repress, though between Magna Charta and 1809 above twenty acts of Parliament were passed to fix and establish the standard and uniformity of weights and measures. ${ }^{1}$

In the time of Edward II., the town leet juries were instructed to inquire and declare

of every breach of the assize of bread, beer, wine, cloth, weights, measures, beams, bushels, gallons, ells, and yards, and of all false scales, and of those who have used them. ${ }^{2}$

This was, there can be no doubt, an ancient practice at that time. Each little community had its own standard, and as the township merged into the parish, so the keeping of the local weights and measures passed from the town-reeve or elder to the parish priest. ${ }^{3}$ These again were superseded under various charters and acts of Parliament by mayors, bailiffs, stewards, and the like officials. Thus the Statutum de Pistoribus, etc. (or Statute concerning Bakers), which is variously attributed to 51 Henry III. (1267), and to 13 Edward I. (1285), enacts that the standard of bushels, gallons, and ells shall be sealed with the iron seal of the king, and shall be kept safe under a penalty of $£ 100$, and that no measure shall be in any town unless it do agree with the king's measure, and be marked with the seal of the commonalty of the town. By the 7 Hen. VII., c. 3, 1491, it was enacted that standard measures and weights of brass should be delivered by indenture from the lord treasurer to the representatives in Parliament, or the chief officers of the cities, towns, and boroughs of every shire, to be conveyed at the cost and charges of such cities, etc., and to be delivered to, and remain in, the custody of the mayors or other chief officers of the same to the intent

1 Blackstone's Commentaries, vol i, p.
275 , n. 16. 15th edition, 1809 .
2 Horne's Mirror of Justice, temp. Edward II., chap. i, sec. 17. Cited
Journal of the British Archmological Association, vol. viii, p. 314.

3 The Conquest of England, by J. R.

Green, p. 15. 
that as well all measures and weights within the said cities, etc., may be corrected, reformed, amended, and made, according and after the measure of the said standard. And that the chief officer for the time being, in every such city, etc, have for that cause a special mark or seal to mark every such weight and measure, so made, to be reformed and brought unto him without fraud or delay, etc., etc.

Four years after the date of this statute, viz., in 1495, 11 Hen. VII, c. 4, another was passed, containing similar enactments, but with some additional clauses, to the following effect, viz. : That every mayor, etc., having the standard weights and measures, should have authority to make a sign and print (that is, a seal or mark) with the letter $\mathrm{H}$ crowned to sign and print like weights and measures unto every the king's lieges and subjects duly requiring the same. This device, the crowned initial of the sovereign, has been used ever since.' The Elizabethan bye-law of the city of Carlisle, No. 70, runs thus :

Item, that the comone seales wherewth bushells, half bushells, pecks, etc., is sealed shall all waies remain or be hereafter in the kepinge of the mayr and in non other officer.

'The 79th bye-law provided as follows-

Item that the mayr and balifs shall yerely take veu of all measures and metts $w^{\text {thin }}$ this citie ons in the yere And if they fynd any unlawfull measure either bushell half bushell peke half peke galone yard wands or other measures that then the mayr and balifs to brek them and evere of them and cause new to be providt $\mathrm{Yf}$ any man kepe in his house any double measure that is to say a gret one to by $\mathrm{w}^{\text {th }}$ and a lesse to sell $\mathrm{w}^{\text {th }}$ that euere one offendinge therein shall pay for euere severall offence vis and viiid.

A schedule to the act of 11 Hen. VII. contains the names of towns limited for the safe custody of weights and measures, according to the king's standard; amongst which are-

Westmoreland $\quad \ldots \quad \ldots$ Town of Appleby,

Cumberland _... ... City of Carlisle.

This act was amended in the following year, as the standards had turned out defective, and had to be recalled and re-issued again.

1 I am indebted to an article by $\mathrm{Mr}$. Brewer, in the Journal of the British
Archæological Association, vol. viii, for much of the above. 
In the reign of Queen Elizabeth, it appears from a royal roll, dated $17^{\text {th }}$ June, 1588 , and addressed to the Barons of the Exchequer ${ }^{1}$ that great complaints had arisen that "the weights used throughout this our realm were uncertain and varying one from another," and that a jury had been appointed in 1574 to make standards of troy and avoirdupois weights. This was done, but in a short time it was discovered that the new standards were wrong; they were recalled, and in 1588 new ones were again made and issued to the cities and towns specified in the act of Henry VII, and to some additional places. The standards issued in 1588 remained in force until 1824: they are of elegant form, as may be seen from the examples from Carlisle now placed upon the table, and from the engravings in the seventh report of the Warden of the Standards, which by the kindness of the Controller of H.M. Stationery Office are reproduced with this paper. It has been conjectured that these standards were made from ordnance taken from the Spanish armada. ${ }^{2}$

In 1601 standard measures of capacity were also issued; we reproduce an engraving of the standard quart also

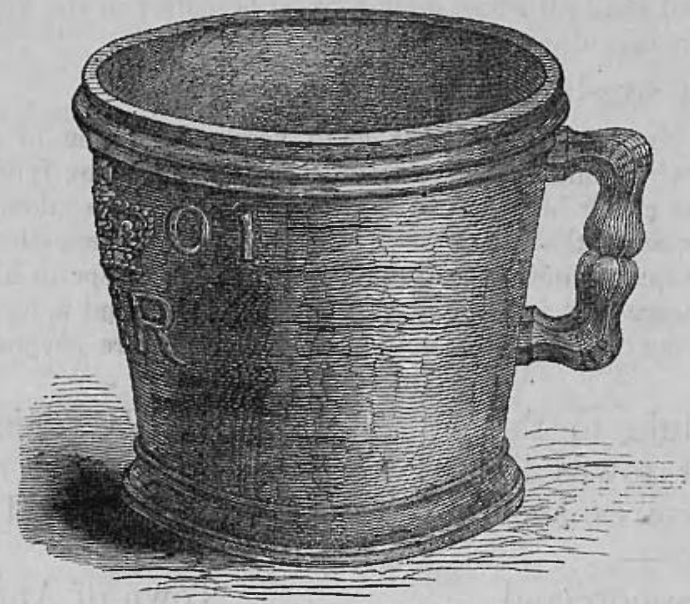

Standard Quart.

from the "seventh report," etc. We have not so much information as to the making of these standards of capacity, as we have as to the troy and avoirdupois ones. See the seventh report of the TVarden
of the Standards.
2 Journal of the British Archcoological Association, vol. viil, p. 370 . 
In the seventh volume of the "Transactions of the Cumberland and Westmoreland Archæological Society," p. 56 , is printed-

A note of all sortes of weights as well brasse or lead with a note of the plait ard their weight, the bookes and other implements belongin to the Cittie bye Matthew Cape Maior, the $14^{\text {th }}$ November, 1627-Avertepoys or bell li li li li li li li weights $\begin{array}{lllllll}56 & 28 & 14 & 7 & 4 & 2 & 1\end{array}$

Stolen by Keethe

Averdepois round and li li li li oz.

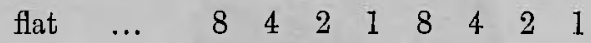

Troy Weight : per oz.

ounces $256228^{1}$ [sic] $\begin{array}{llllllllllll}64 & 32 & 16 & 8 & 4 & 2 & 1 & \frac{1}{2} & 0 & \frac{1}{x} & 0 & 0^{2}\end{array}$

Lead weights in the charge of the weightman.

1 brasse bushell 1 feardlet

1 brasse gallon $\quad 1-2^{\mathrm{li}}$ pound

1 halfe gallon 1 one pound

1 quart

1 halfe a pound

1 quartere.

How many of these weights the old corporation of Carlisle still had in their possession, when they were reformed in 1835 , I cannot say, but the reformed corporation sold to the best bidder the standard weights and measures, which had been superseded in 1824. Some of these

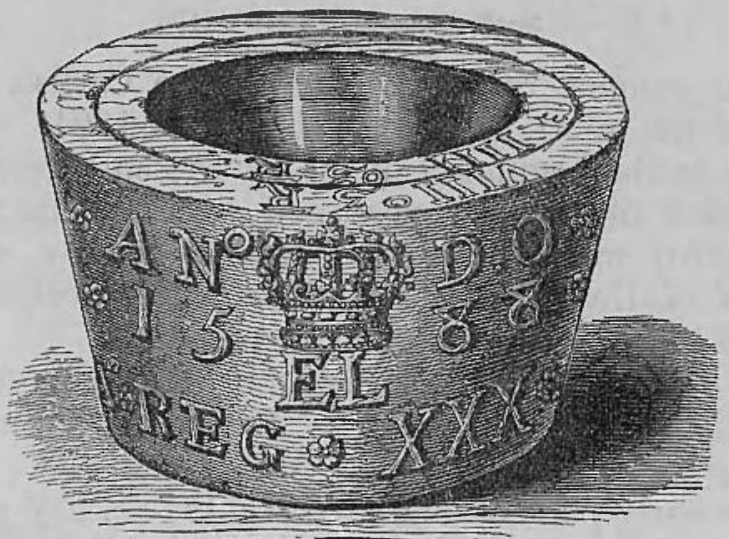

Standard troy weights for 4 and 8 ounces.

I have been able to trace and now exhibit, viz. six of the standard troy weights, six cups, or rather hollow frustra of cones fitting one into another ; they are the weights for

${ }^{1}$ A mistake for 128 .

2 Do not the ciphers denote weights 
$4,8,16,32,64,128$ ozs., and are kindly lent me by Mr. Wheatley, whose father purchased them in 1835 from the corporation. Mr. Carrick, of Lonsdale Street, has two of the avoirdupois bell weights, those for one pound

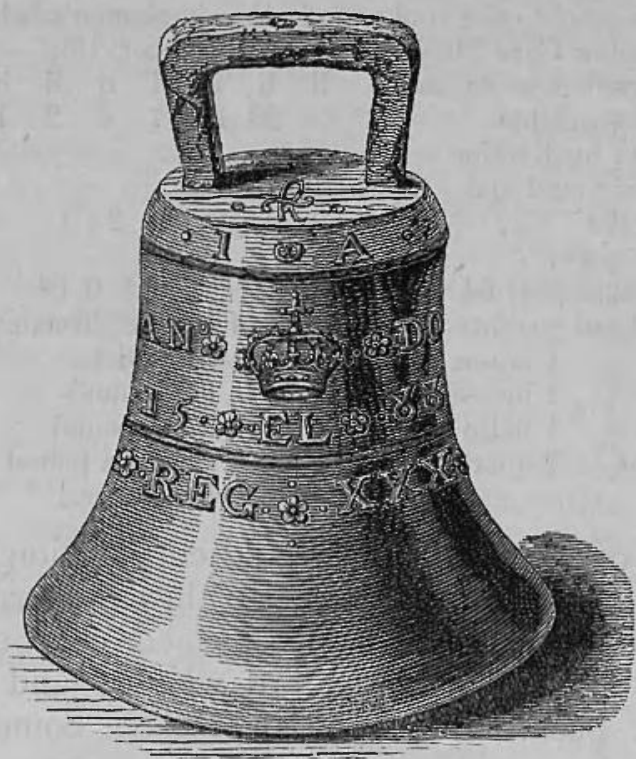

Standard avoirdupois weight for $1 \mathrm{lb}$.

and two pounds respectively; and the Carlisle museum possesses the quart, gallon, and bushel of 1601 .

Thus, at the beginning of the seventeenth century, the corporation of Carlisle possessed standard measures of weight (troy and avoirdupois) and of capacity, satisfying the acts of Henry VII, and duly authenticated by the crowned initial of the reigning sovereign.

How comes then the Carlisle bushel of 24 gallons to have been in use until lately? Let us try to investigate its history.

In the early part of the seventeenth century great litigation' took place at Carlisle, York, and London, about the tithes of the tenants of Holm Cultram, and one of the points involved was-by whose bushel was the tithe to be measured, by the abbot's bushel of 8 gallons, or by the bigger bushel of the mayor of Carlisle. The point was

1 The information as to this litigation is from a large manuscript volume of papers relating $t s$ the parish and manor of Holm

Cultram lent me by Messrs. Lawson of Wigton. Several copies of this book exist. 
one worth the contesting, for the tithe of meal amounted to 938 bushels 1 peck; of barley to 581 bushels, and of oats 63 bushels 2 pecks, besides money in lieu of tithe. The tenants contended that they always paid by a bushel kept by the abbot of the dissolved monastery, and called the abbot's bushel, which was in existence at the time of the litigation. The farmers of the tithe contended that they should be paid by the Carlisle bushel of 20 gallons (20 gallons not 24.) An affidavit was put in by the mayor of Carlisle, Henry Baynes,

that they found Carlisle measure for corn to contain 20 gallons to the bushel ; this was all his remembrance and then out of mind (as he hath heard) doth not know of the plaintiffs (the tenants) paying corn or meal by a bushel. Since he was mayor he caused the measures for buying and selling of corn there to be made, the one of 16 gallons (called a bushel) and the other the half bushel of 8 gallons; the plaintiffs may use which they like best and they are at no prejudice by the bushel of 20 gallons, intending to leave this bushel of 20 gallons (as he found it), being the cities, who desire the continuance of it with the consent of most of the country.

From this it would seem that Baynes, who was mayor in 1601, found the citie in possession of a bushel measure holding 20 gallons, and that he made one to hold 16 gallons and a half one to hold 8.

In the course of the suit it was admitted that Mr. Mayor Baynes

during his mayorality caused other measures of 8 gallons, after the lesser measure, to be made, and gave them to those that kept the measure there, that those that would might buy by them. But the country, desirous to keep the old measure, never used the new.

An undated order of the Exchequer finds

That the Tenants \&c. have Time out of Mind and Memory of Man used and were accustomed to pay their tithe corn, \&c. to the said late Abbot and his predecessor abbots there after the Rate and Measure of Carlisle Bushel commonly used there. But herein was a great Error committed by the Magistrates by Increase of Carlisle Bushel to 10, 12, and 14 Gallons contrary to the Statute of 8 Gallons in the Exchequer at that time and in Queen Elizabeth's time to 16,18, and 20 Gallons, and in King James' time to 22 and 24 Gallons to a Bushel, which procured a most Huge suit in law before it was burnt at a head (?) assize in the City of Carlisle by Judge Denham upon the 19th of August, 1623.

In another undated paper it is stated that for 60 years past the Carlisle bushel had been 16 gallons equal to 20 Exchequer gallons ; and it further states that in Carlisle market they sell by the bushel heaped up. Now, a 
measure holding 16 gallons when striked, or filled just level with the top, would, if heaped up, be about 20 gallons; this I take to be the explanation of the above, and not that the Carlisle and Exchequer gallons were of different sizes.

We have thus got at the fact that the Carlisle gallon has varied and that it was on the rise between the suppression of the monasteries and the year 1623 ; it had then got to 24 gallons, and spite of the vigorous action of Mr. Justice Denham, it survived at that size down to to-day.

Other mention may be found locally of measures deviating from the Exchequer standard. There was about the same date as, or rather later than, the Holm Cultram litigation, a suit between the earl of Cumberland and his tenants near Appleby, in which was raised the question of by what measure the sergeant's oats or bailiff's corn was to be paid. By a decree dated in 1634 ,

Sir John Lowther was desired to examine and certify concerning the measure, who having examined two old pecks, one containing 8 quarts, and the other 10 striked quarts, both of which had been paid upheaped (which was reckoned one-third more) he, to avoid uncertainty, recommended, and so it was decreed, that instead of the old peck upheaped, they should pay 13 quarts striked.1

It is not said where these old pecks were kept, but most probably at Appleby. The peck containing 8 quarts (that is, two gallons) would be an Exchequer or standard peck; if heaped up it would hold about 10 quarts (that is $2 \frac{1}{2}$ gallons) and the bushel would be 10 gallons; the bigger peck, if heaped up, would hold 13 quarts ( $3 \frac{1}{4}$ gallons) or rather more, and the bushel would be 13 gallons or nearly 14 gallons. We thus get to the steps by which the Carlisle bushel crept up, from the standard of 8 gallons to 10,14, \&c. The suggestion occurs that in the heaping up, we may find the origin of these local measures. A local custom to heap up the 8 gallon bushel, instead of striking it, would make a local bushel of 10 gallons. The local authority would ultimately provide a bushel to hold 10 gallons striked, as at Appleby; this heaped up would give a still bigger bushel, one of 14 gallons, and so the bushel grew. That a custom of paying by the bushel heaped up

1 Burn and Nicholson, vol, i, p. 292. 
existed at Carlisle is proved by entries in "A survey of Church Lands, anno 1649," now in the library at Lambeth, which gives a survey of the possessions of the see of Carlisle, and of the dean and chapter of Carlisle: among the possessions of the latter was the "Meale Garner's Office," which was leased out in various parts, viz. eightb parts : the Meale Garner had to receive certain payments of haver-meal, of bigg and of oats. In the leases occur the following expressions :-

After the proportion of fourteene gallons to the bushel, according to the brasse measure of Winchester.

According to the bushell wherewith farmers and tennants are bound and accustomed to pay the same, viz. 14 gallons of Winchester measure to the bushell.

And

By the measure of twelve bushells every eskepp and sixteen gallons to every bushell of ye sealed brasse gailon.

It is clear that a local custom existed to pay by the bushel heaped up, and, so strong was it, that the dean and chapter insisted on having the heaped up bushel measured by the number of brass standard gallons they considered it would amount to. In the Liber quotidianus contrarotulatoris Garderobce anno regni Regis Edwardi Primi vicesimo octavo, we find grain bought both by mensura rasa or striked measure, and by mensura cumulata or heaped up; and it is stated that 177 quarter aven per mensuram cumulat' faciunt per mensuram rasam 185 quarter $7 \mathrm{bz}$.' This was at Berwick-on-Tweed, and as the comptroller takes the trouble to reduce the mensura cumulata into mensura rasa, he clearly bought by the measure heaped up, but kept his accounts by the measure striked or standard measure, thus showing that the Berwick peopleas well as the Carlisle-had a custom to sell by the standard measure heaped up. 